\title{
The Challenge of Sustainable Consumption for Governance and Policy Development-A Systematic Review
}

\author{
Vivienne Byers * and Alan Gilmer (1D \\ Environmental, Sustainability \& Health Institute, Technological University Dublin, Grangegorman, \\ D07 H6K8 Dublin, Ireland; alan.gilmer@tudublin.ie \\ * Correspondence: vivienne.byers@tudublin.ie; Tel.: +353-1-402-3806
}

Citation: Byers, V.; Gilmer, A. The Challenge of Sustainable

Consumption for Governance and Policy Development-A Systematic Review. Sustainability 2021, 13, 6723. https://doi.org/10.3390/su13126723

Academic Editor:

Francesco Caracciolo

Received: 24 March 2021

Accepted: 20 May 2021

Published: 14 June 2021

Publisher's Note: MDPI stays neutral with regard to jurisdictional claims in published maps and institutional affiliations.

Copyright: (c) 2021 by the authors. Licensee MDPI, Basel, Switzerland. This article is an open access article distributed under the terms and conditions of the Creative Commons Attribution (CC BY) license (https:/ / creativecommons.org/licenses/by/ $4.0 /)$.

\begin{abstract}
The modern industry discourse on sustainability is the idea of 'green growth', which is described as the paradox of the continuation of increased economic growth, at the same time as increasing sustainability. Policy makers face the challenge of how to encourage and sustain appropriate levels of individual behavioural change to manage consumption in a changing environment. In addressing this challenge, this study seeks to move beyond discrete elements of human consumption behaviour and develop a better understand of the wider inputs including culture, societal norms, institutions and governance. The research methodology adopted uses a systematic literature review approach coupled with thematic analysis. The study presents a new understanding of the interrelatedness of consumption policy, social structures, and the boundary arrangements of governance. What emerges is a focus on the role of governance and societal context in influencing outcomes. A fundamental output of the study is the designation of 27 evidence-based principles of change. These principles represent a new framework: the Governance and Sustainable Policy Development (GSPD) framework or 'Road Map', designed to guide decision making and aid the understanding of what motivates individuals and institutions within a wider neo-liberal societal system to manage their consumption from a more sustainable policy and governance perspective.
\end{abstract}

Keywords: consumption; sustainability; governance; society; values; environment

\section{Introduction}

Improving the sustainable behaviour of communities and individuals through informed public and social policy has never been direct or clear, however the need for such change has never been greater [1]. There is a need to gain a better understanding of individual values and motivations that influence sustainable consumption behaviour. Theoretically, the field of behavioural management in environmental consumption is much contested [2-4]. Considerable debate continues regarding behavioural change and policy learning at both an individual and societal level and in relation to the balance of responsibility between these two levels [5]. Indeed, the ways in which ordinary people deal with environmental matters requires detailed examination, in how they perceive, understand, evaluate, and manage the connections between their personal lifestyles and routine consumption practices and global environmental change [6]. Policy makers seek to gain a better understanding of these everyday consumption practices of consumers in order to reduce overall environmental impact in areas such as $\mathrm{CO}_{2}$ transport emissions or energy consumption [7]. However, these consumption processes are nested within societal values and systems influencing both intrinsic as well as extrinsic motivation, in terms of citizen empowerment, governance and sustainable policy development.

This is a rapidly expanding area of research for those in public and social policy, as well as in science and business. Consequently, there are numerous avenues for the engagement of management scholars and educators in addressing these grand societal challenges [8]. Indeed, management scholars have been widely encouraged to engage 
in tackling these broader societal challenges through their collaborative research and collective insight [8]. Although many different disciplines are addressing the problems of managing sustainability, there are many challenges to this process, including agreeing common definitions of sustainable behaviour, the policy implementation gap in terms of the limited persistence of change in behaviours, as well as the paternalistic perspective in assessing consumption without regard of the societal context. Thus, there is a need to develop a greater understanding of the setting in which decisions are made, whether by organisations or individuals, and to acknowledge the twin dimensions of societal dynamics and the complexity of the interactions within the concept of sustainability. This paper aims to contribute to conceptual development in influencing sustainability-oriented behaviour within a policy and governance context, and provides initial guidance from a wider disciplinary perspective. Bringing together findings from a diverse body of literature across the science, social-science and business disciplines, the authors review and integrate findings and, in so doing, inform a synthesised review in order to move to a new evidenceinformed societal paradigm.

\section{Managing Societal Sustainability}

National and local policy makers have sought to encourage individuals to engage in a wide range of pro-environmental practices to address both discrete environmental problems and major global challenges such as climate change [9]. In the Irish context, much useful work has been conducted in encouraging individual consumers to manage their consumption behaviour [10-12]. However, despite considerable work nationally and internationally, progress has been slow and both theoretical and applied dimensions of behavioural management in environmental consumption are highly contested [3,4].

This paper explores the context of human consumption behaviour nested within wider society and its values, which is now increasingly under pressure to respond to a changing environmental system. Sustainable consumption behaviour in the context of climate change is a grand challenge that has been characterised as a "super wicked" problem because of the scale, scope, and time horizon over which mitigation efforts must take place, without central authority [8]. They note that corporate responses to such challenges may be visionary and expansive initially, although become diluted over time due to the sheer contentiousness of the issues. The modern industry discourse on sustainability is the idea of 'green growth', which is a paradox of continued economic growth in the context of promoting increased sustainability [3]. Policy makers view the challenge as encouraging and sustaining appropriate levels of individual behavioural change to manage consumption $[13,14]$. However, questions remain regarding the claims of a 'green economy', because large-scale de-carbonisation of the economy and society will only be achieved if current consumption patterns, methods and lifestyles are subject to change [15]. Indeed, it has been suggested that nothing short of absolute decoupling of growth and resource consumption is needed to achieve sustainability and stabilise the impacts of climate change [16].

From a societal perspective, the UN Sustainable Development Goals (SDGs) address some of the grand challenges that now face the planet, but the question remains of how to move current systems of behaviour in society to a new, more sustainable state, given the embedded uncertainties and complexities of such a process. A framework of behavioural approaches to the governance of sustainable consumption can be used to interrogate the literature for a wider analysis centred around the utilitarian, the social/psychological, and the systems of provision/institutional approach [3]. These concepts inform the selection of policy tools to change behaviours and modes of governance and can act as policy paradigms or belief systems [17]. The first, the utilitarian approach, underlies much contemporary neo-liberal economic policy [18]. It is based upon the belief that individuals consume goods and services in free markets with perfect competition and information to decide a course of action that delivers the greatest personal utility. This affords an opportunity to micro-focus on the inconsistency of consumer attitudes and behaviours. The second 
approach, the social/psychological model, includes both behavioural economics and social marketing, and has emerged as a critique of the first approach. This approach considers the role of the individual within society as a citizen-consumer. Behavioural economics stems from the belief that individuals "satisfice" by choosing options that satisfy most needs but are not individually optimal [19]. This has resulted in the growth of 'nudging' which seeks to configure a choice array in a policy instrument for citizens so that they are steered towards making positive decisions for society while preserving individual choice $[3,20]$. The main focus of behavioural change from a consumption studies perspective is via the tool of social marketing, which utilises softer powers to build public awareness and change behaviour through the gradual establishment of new, and collectively held, behavioural norms [21]. Again, this approach is not without its critics as being paternalistic and without regard to the individual's decision-making context $[4,22]$. The third approach is the systems of provision/institutional approach (socio-technical), which considers individual psychological factors and values within the context of the systems, standards and norms under which individuals operate $[3,23,24]$. Understanding this is fundamental to the development of successful strategies and policies to shift towards sustainable consumption [25]. This approach addresses the systematic, structural, and institutional perspectives on how institutions, through public policy initiatives, can begin and sustain change towards sustainability in the future. It considers the values (both intrinsic and extrinsic) of the individual within the context of the constraints and norms of institutions and wider society.

In seeking to define value systems in society, which in turn define behavioural patterns of consumption at the governmental, institutional, community and individual levels, this paper assesses the diverse literature on the topic of environmental sustainability, consumption and sustainability, and institutional and societal sustainable behaviour, and therefore can inform sustainable policy development and governance. It also explores the societal framework within which individuals make decisions that define sustainability. In order to achieve these aims, a systematic literature review (SLR) methodology was chosen to:

- Establish the extent to which existing research has progressed towards generating methodologies, tools and templates that facilitates the development of sustainable policy;

- Identify relationships, contradictions, gaps, and inconsistencies in the literature on sustainable behaviour in Irish, European, and Western societies;

- Explore reasons for the diversity of perspectives presented in the literature on sustainability as a process and to propose new conceptualisations or theories that may account for these inconsistencies;

- Disaggregate and map the components and dynamics of sustainable governance and societal and individual sustainable behaviour;

- Inform an overarching conceptual model for the development of policy that nurtures and advances behavioural dynamics at the institutional, community and individual level towards a more environmentally sustainable state.

The challenges to sustainability and sustainable development have been amplified by the continued growth of the global economy [26]. Therefore, the problems related to unsustainable consumption are growing, and the approach to addressing them must become more intentional, comprehensive, and systematic [23]. A key challenge to green governance, sustainability and sustainable consumption has been the dominant social paradigm (DSP), which can be characterised by a belief in unlimited abundance and progress, materialism, faith in the power of technology, minimal government intervention, and unlimited private property rights which greatly define our neo-liberal discourse [23,27-29]. In the wider European context, there is a call for improved governance across all sectors in order to manage sustainable consumption [30]. The link between sustainability and health and well-being has been explicitly set out [31]. A clear need has been identified to create an environment where every individual and sector of society can play their part in achieving 
a 'good society'. However, this can only be achieved through society-wide involvement in, and engagement with, cross-sectoral sustainability linking governance, environment, economy and human health. This paper seeks to explore this challenge and offer insight on how this might be addressed.

\section{Materials and Methods}

\subsection{A Systematic Literature Review}

A systematic literature review (SLR) and meta-analysis is an essential tool for summarising evidence accurately and reliably. The use of an SLR approach facilitates the interrogation of broader questions than a single empirical study can address [32]. Indeed, the SLR methodology has the potential to provide insight to some of the most important contributions to understanding and practice implementation, and seeks to provide a rigorous foundation for the advancement of knowledge. The approach is characterised by being objective, transparent and replicable. The SLR involves a systematic search process which collates empirical evidence that fits pre-specified eligibility criteria to answer a specific research question or set of questions.

Three phases in the literature search process have been distinguished [33], and this staged approach was used in the development of the methodology for this study.

(i) A conceptual framework was developed based on a review of methodological literature and defines the three key areas of enquiry, i.e., the utilitarian approach and consumer responsibility, the social/psychological approach, and the socio-technical (systems of provision/institutional) approach [3]. This framework represents the initial 'architecture' for reviewing the wider literature, its underlying assumptions and key dimensions. It also provided insight in terms of context and the development of concepts to enable a deeper interrogation of the topic and to provide the necessary consistency and scientific structure in addressing the research questions. Additionally, outputs of this review process provided guidance on the key search terms to be used in the SLR and on the generation and selection of the grey literature (GL);

(ii) This was followed by a full systematic review of the literature as per SLR protocols, which utilise five steps in producing a systematic review: formulating the question(s); locating studies; study selection and evaluation; analysis and eligibility; and reporting results [34-36];

(iii) The outputs of this process were then subjected to concept mining, data evaluation, coding and framework synthesis utilising thematic analysis [37], as it is shaped, reinforced and refined by findings from the included studies [38,39].

The initial conceptual framework (phase (i)) was further developed by incorporating the agency role inherent in approaches to sustainable consumption [40,41]. This included the consideration of individual or consumer responsibility, individual or community consumption situated within wider social, economic and technological structures, and then 'systemic' conceptions of consumption as socio-technical systems. In this respect, socio-technical systems are conceived of as imbedding the possibilities of a transition to greater 'societal' responsibility and the involvement of wider institutional actors $[5,42]$.

Thus, utilising the initial conceptual framework, the second phase in developing the SLR approach was mapped out. This involved formulating the core research questions:

- What societal dynamics drive consumption behaviour and how is environmental sustainability integrated into the decision-making process at a governance, institutional, community and individual levels?;

- What intrinsic and extrinsic dimensions of society control sustainable behaviour and decision making at the individual, institutional, community and governance levels?;

- What is the most effective approach (road map) to the design of strategies, policies, initiatives, programmes and plans that can advance individual and societal behaviour and institutional and governance systems towards a more environmentally sustainable state? 
From these questions, the key search terms were identified with Boolean terms applied to control search dynamics. The derived search terms and the associated Boolean operators included: sustainable ' $o r$ ' sustainability; ' $a n d$ ' environment 'or' environmentally; ' $a n d$ ' consumer behaviour 'and' governance 'and' policy 'and' values 'and' intrinsic 'and' extrinsic. The OneSearch search engine was used because it is a simple and effective overarching database interrogation system which brings together article-level content across a large selection of journals, periodicals, books and other databases. This study used a OneSearch system incorporating 89 databases including Scopus, JSTOR, Web of Science and the Social Sciences Citation Index. The characteristics and nature of the data source were deemed essential in determining the relevance and validity of a given paper or study within the SLR process, which was confirmed by reference to a range of inclusion and exclusion criteria (Table 1). These criteria included the search time frame, the type of publication, the discipline type and the nature of record display (e.g., full text), and the language of publications (e.g., English).

Table 1. Inclusion and exclusion criteria for the SLR.

\begin{tabular}{|c|c|c|}
\hline Inclusion Criteria & Categorisation & Justification \\
\hline $\begin{array}{l}\text { Includes reference to } \\
\text { sustainability, environment } \\
\text { and society }\end{array}$ & $\begin{array}{l}\text { Topic/Discipline/Theory } \\
\text { Focus }\end{array}$ & $\begin{array}{l}\text { Links sustainability and the natural environment with social } \\
\text { systems, behavioural systems and their operating context. }\end{array}$ \\
\hline $\begin{array}{l}\text { Addresses sustainable } \\
\text { management or practices }\end{array}$ & Practice/implementation & $\begin{array}{c}\text { To include studies that have demonstrated a practice or assessment } \\
\text { or implementation focus. To ensure the inclusion of organisational } \\
\text { and operational dimensions, as well as aspects of preservation, } \\
\text { biodiversity, and ecosystem welfare. }\end{array}$ \\
\hline $\begin{array}{l}\text { Environment and } \\
\text { ecosystems }\end{array}$ & Definition & To include reference to the natural environment and ecosystems. \\
\hline Consumer behaviour & Definition & $\begin{array}{c}\text { To ensure inclusion of all relevant publications that are concerned } \\
\text { with sustainable consumption, consumers/behaviour, and the } \\
\text { consumption of natural resources. To ensure the inclusion of } \\
\text { stakeholders and market dimensions. }\end{array}$ \\
\hline Governance & Definition & $\begin{array}{l}\text { To ensure inclusion of all relevant publications that are concerned } \\
\text { with social control and governance systems. }\end{array}$ \\
\hline Policy & Definition & $\begin{array}{c}\text { To ensure inclusion of publications that address the issue of policy } \\
\text { associated with sustainability, environment and guiding } \\
\text { behavioural outcomes, including the consumption of natural } \\
\text { resources by society. To identify policy as a term related to the } \\
\text { preceding search terms. }\end{array}$ \\
\hline Value/s & Definition & $\begin{array}{l}\text { To identify papers that address societal values in the consumption } \\
\text { of natural resources. To ensure the inclusion of financial and } \\
\text { economic considerations and those that address ethical, moral and } \\
\text { aesthetic principles and the role of belief systems, social norms and } \\
\text { behaviour. }\end{array}$ \\
\hline Intrinsic & Definition & $\begin{array}{l}\text { To include papers that address intrinsic characteristics which are } \\
\text { defined by the thing having value "in itself," or "for its own sake," } \\
\text { or "as such," or "in its own right." }\end{array}$ \\
\hline Extrinsic & Definition & $\begin{array}{l}\text { To include papers that address values defined by a derived good; it } \\
\text { is a good not for its own sake, but for the sake of something else } \\
\text { that is good and to which it is related in some way (as such the } \\
\text { latter is reflective of the former). }\end{array}$ \\
\hline All Fields & $\begin{array}{l}\text { All sections of the document } \\
\text { to be included }\end{array}$ & $\begin{array}{l}\text { This ensures that all sections in the selected documents are screened } \\
\text { by the database search engine for inclusion of the search terms. }\end{array}$ \\
\hline
\end{tabular}


Table 1. Cont.

\begin{tabular}{|c|c|c|}
\hline Inclusion Criteria & Categorisation & Justification \\
\hline $\begin{array}{l}\text { All disciplines and research } \\
\text { domains }\end{array}$ & Discipline type & $\begin{array}{c}\text { To ensure that the search is not restricted by any discipline or topic } \\
\text { area. }\end{array}$ \\
\hline $\begin{array}{l}\text { Studies since 1st January } \\
\qquad 2002\end{array}$ & Time Frame & $\begin{array}{l}\text { Limited by time because this is the period with the greatest number } \\
\text { of contributions and the most relevant type of contribution to the } \\
\text { topic of interest. }\end{array}$ \\
\hline $\begin{array}{l}\text { Book/eBook, Book Chapter, } \\
\text { Journal/e-Journal, Journal } \\
\text { Article }\end{array}$ & Document types & $\begin{array}{l}\text { To ensure only contributions included in published books and } \\
\text { peer-reviewed articles were selected. }\end{array}$ \\
\hline Full text online & Search Display Format & $\begin{array}{l}\text { The ensure that the full content and contribution of the articles and } \\
\text { studies concerned were accessible for review and evaluation. }\end{array}$ \\
\hline $\begin{array}{l}\text { Scholarly material including } \\
\text { peer reviewed papers and } \\
\text { studies }\end{array}$ & Search engine parameter & $\begin{array}{l}\text { To target seminal theoretical developments and contributions in the } \\
\text { academic literature. }\end{array}$ \\
\hline $\begin{array}{l}\text { Include results beyond the } \\
\text { library collections of the } \\
\text { Institution concerned (TU } \\
\text { Dublin) }\end{array}$ & Search engine parameters & $\begin{array}{l}\text { To ensure that all relevant articles, papers and studies were } \\
\text { included in the SLR search process. }\end{array}$ \\
\hline English & Language & $\begin{array}{l}\text { Articles either fully written in English or with an English language } \\
\text { Abstract because English is the academic reference language. }\end{array}$ \\
\hline Exclusion Criteria & Categorisation & Justification \\
\hline Before 1st January 2002 & Time Frame & $\begin{array}{l}\text { Studies before this date are less relevant to current theoretical } \\
\text { developments. The most significant contributions on sustainability } \\
\text { and consumption have been published since 2002, and hence the } \\
\text { reference period selected is proportionally more important. }\end{array}$ \\
\hline $\begin{array}{l}\text { Non-English language } \\
\text { papers }\end{array}$ & Language & $\begin{array}{c}\text { Based on the academic norm that all significant academic } \\
\text { contributions have an Abstract available in English (even if } \\
\text { published in another language). }\end{array}$ \\
\hline $\begin{array}{l}\text { Newspaper articles, book } \\
\text { reviews and dissertations }\end{array}$ & Document type & $\begin{array}{l}\text { In the context of this study, newspaper editorial comment, general } \\
\text { book reviews, advertisement features, trade articles and } \\
\text { dissertations do little to advance the research topic. It is noted that } \\
\text { outputs of meritorious dissertations will have generated } \\
\text { peer-reviewed academic publications, and if relevant, these will be } \\
\text { identified through the publication path. }\end{array}$ \\
\hline
\end{tabular}

The nature of sustainability and the challenges of environmental change have generated a substantial number of contributions from a wide range of disciplines and fields of interest, particularly over the last two decades. In this regard, it was important to ensure that the selected search terms and inclusion and exclusion criteria were designed with an appropriate level of specificity. This was required to generate higher precision in the selection of studies and hence improve the quality and confidence that can be placed on the conclusions and outcomes of analysis. The inclusion-exclusion criteria were designed to show full text articles and to select all scholarly material, including peer-reviewed articles. It was decided to search from 2002 (Rio + 10 Summit) on the basis that this is the most relevant period for review given the contemporary nature of the research topic and the rapid and dynamic changes in society and the shifting global perspective on the sustainability of the anthropic-environmental nexus.

The process of assessing papers and articles was mapped using the Preferred Reporting Items for Systematic Reviews and Meta-Analyses (PRISMA) scheme, which was adopted and tailored to the needs of this study [43]. PRISMA focuses on ensuring the transparent and complete reporting of the systematic review process and involves the steps of (i) identification, (ii) screening, (iii) eligibility, and (iv) inclusion. This approach 
used a matrix-based technique similar to that used elsewhere for data analysis in primary qualitative research [44]. Hence, the SLR papers generated by the search terms (step (i) identification as per Table 1) were then subjected to preliminary analysis (step (ii) screening) as per Table 2, which generated a refined list of papers or core papers.

Table 2. Screening selection of the SLR papers (papers must comply with the screening-eligibility criteria to remain included in the core list).

\begin{tabular}{lll}
\hline Screening Criteria & Categorisation & Comment/Analysis \\
\hline Duplicate Papers &
\end{tabular}

\begin{tabular}{lll} 
Duplication of a paper & $\begin{array}{l}\text { Duplication, } \\
\text { Duplicate entry }\end{array}$ & $\begin{array}{l}\text { The Search Terms and Inclusion/Exclusion } \\
\text { criteria when used on the literature databases } \\
\text { can generate some duplicate outputs- these } \\
\text { need to be filtered. }\end{array}$ \\
\hline
\end{tabular}

\section{Discipline Focus}

Disciplines/topics that address the research questions

Topic/Scope
Overarching requirements that the key concepts/topics of this research study are addressed in the paper being assessed, to ensure that relevant work is included.

\section{Research Question Focus}

Studies that address one or more aspects of the research questions.
Q1(a) Are societal dynamics presented that drive consumption behaviour?

Q1(b) Are mechanisms that explain how societal dynamics relate to consumption behaviour included?

Q1(c) Is there consideration of environmental sustainability and its integration into decision making for governments, institutions, communities and individuals?

Q2(a) Are intrinsic dimensions/values of society considered in terms of control of sustainable behaviour and decision making?

Q2(b) Are extrinsic dimensions/values of society considered in terms of the control of sustainable behaviour and decision making?

Q3(a) Are strategies, policies, programmes or plans considered in terms of sustainable development and sustainable behaviour?

Q3(b) Is there an assessment of the nature and effectiveness of approaches to the design of policies, programmes and plans as tools to advance sustainable behaviour?

Q3(c) Are the efficacies of policies, programmes and plans to shape individual/societal behaviour and institutional and governance systems assessed?
Paradigm/theory

Driving parameters

System understanding

Translational process and mechanism. environment and consumption.

Influence of setting and context.
This identifies papers that link concepts of control, policy, governance, sustainability,

How sustainability problems are managed by different sectors.

How are value systems understood and how do they influence behaviour?

How are value systems understood and how do they influence behaviour?

What are the major tools of sustainable behaviour management in society?

Development protocols Strategies in policy, programme and plan design.

Follow-up, assessment and the feedback system in policy implementation. 
Table 2. Cont.

\begin{tabular}{|c|c|c|}
\hline \multicolumn{3}{|l|}{ Exclusion topics } \\
\hline $\begin{array}{l}\text { Articles/Papers/documents dealing with } \\
\text { sustainability from a predominantly } \\
\text { economic perspective or where the } \\
\text { environmental reference excludes the } \\
\text { natural/ecological environment., e.g., } \\
\text { corporate environment, operating } \\
\text { environment, sustainable or sustainability in } \\
\text { reference to market or corporate durability, } \\
\text { etc. }\end{array}$ & $\begin{array}{l}\text { Definition for environment } \\
\text { and sustainability. } \\
\text { Although not absolute, this } \\
\text { typically includes reference to: } \\
\text { Markets; } \\
\text { Finance; } \\
\text { Time; } \\
\text { Spatial references, etc. }\end{array}$ & $\begin{array}{l}\text { To exclude studies that use an alternative } \\
\text { conceptualisation of the terms 'environment' } \\
\text { and/or 'sustainability', and hence do not } \\
\text { address the natural/ecological environment. }\end{array}$ \\
\hline
\end{tabular}

\subsection{Eligibility and Data Extraction}

Finally, an a priori data extraction and analysis template was developed with reference to the conceptual framework set out earlier in the paper [3] and incorporating the focus of the research questions. The data extraction process also drew input from the Cochrane Consumers and Communication Review Group's data extraction template and the ENTREQ guideline (for enhancing transparency in reporting the synthesis of qualitative research) [45]. This resulting framework template (Table 3) was then used to determine the eligibility of the remaining core papers for inclusion in the study. It was also used to contextualise, evaluate and code the data from the core papers identified through the selection process and to provide the basis for the thematic grouping of their contribution to knowledge and understanding (Section 2.1, Phase (iii)). This phase was advanced through an iterative and structured analysis of the content and themes presented in the refined set of core papers. It was also informed by an analytical approach incorporating actor identification and agency [42].

Table 3. Eligibility assessment template.

\begin{tabular}{|c|c|c|}
\hline Eligibility Criteria & Categorisation & Comment/Analysis \\
\hline \multicolumn{3}{|c|}{ Bibliographic Characteristics } \\
\hline Journal Title & Label & Classification of type \\
\hline Paper Title & Label & Classification of focus/topic/theme \\
\hline Authors/Institution & Identity & Contributors, research team and affiliation/s \\
\hline Year & Time & Age of article \\
\hline \multicolumn{3}{|c|}{ Discipline Focus and Thematic Boundaries } \\
\hline $\begin{array}{l}\text { Disciplines/topics that address } \\
\text { the Research Questions }\end{array}$ & Prioritisation & $\begin{array}{l}\text { Select articles which make a significant contribution to the } \\
\text { core topics stemming from the research questions. Articles } \\
\text { must make a substantial contribution to the theme of the } \\
\text { research questions: } \\
\text { - What societal dynamics drive consumption behaviour } \\
\text { and how is environmental sustainability integrated } \\
\text { into the decision-making process at a governance, } \\
\text { institutional, community and individual level?; } \\
\text { What intrinsic and extrinsic dimension of society } \\
\text { control sustainable behaviour and decision making at } \\
\text { the individual, institutional, community and } \\
\text { governance level?; } \\
\text { What is the most effective approach (road map) to the } \\
\text { design of strategies, policies, initiatives, programmes } \\
\text { and plans that can advance individual and societal } \\
\text { behaviour and institutional and governance systems } \\
\text { towards a more environmentally sustainable state?; }\end{array}$ \\
\hline Brief Summary of article & Topic/Scope & $\begin{array}{l}\text { The summary should be informative in terms of the } \\
\text { research questions, particularly regarding sustainability and } \\
\text { socio-cultural dimensions of consumption policy and } \\
\text { related key issues. }\end{array}$ \\
\hline
\end{tabular}


Table 3. Cont.

\begin{tabular}{|c|c|c|}
\hline Eligibility Criteria & Categorisation & Comment/Analysis \\
\hline Aims of the paper/document & Focus & $\begin{array}{l}\text { Indicate aims of the paper/article (possibly provide a list of } \\
\text { aims). Indicate whether the paper deals with general issues } \\
\text { or more concrete problems and solutions or both. }\end{array}$ \\
\hline Participating Institutions & Actors involved & $\begin{array}{l}\text { To identify the driving parties involved in sustainable } \\
\text { management and the governance response in policy design } \\
\text { and implementation. }\end{array}$ \\
\hline $\begin{array}{l}\text { Recipients (targets) of the } \\
\text { policy/schemes }\end{array}$ & Actors involved & $\begin{array}{l}\text { To identify the individuals, communities, industrial sectors } \\
\text { and organisations at which sustainable policy is directed. }\end{array}$ \\
\hline $\begin{array}{l}\text { Specific and Key topics or } \\
\text { themes and concepts of the } \\
\text { article/document }\end{array}$ & Themes and concepts & $\begin{array}{l}\text { Sustainability and consumption-to identify the } \\
\text { contribution to concept development, theory, policy } \\
\text { development, policy implementation design, and } \\
\text { governance and control systems in the social, economic and } \\
\text { political context. }\end{array}$ \\
\hline $\begin{array}{l}\text { Policy Implementation priori- } \\
\text { ties/schemes/mechanisms }\end{array}$ & Protocols and Tools & $\begin{array}{l}\text { Sustainability and Consumption } \\
\text { - Extract information on how any } \\
\text { schemes/programmes/research will be implemented; } \\
\text { - What are the policy priorities if reported and how are } \\
\text { they justified-if at all? }\end{array}$ \\
\hline $\begin{array}{l}\text { Studies that demonstrate } \\
\text { Frameworks and Templates for } \\
\text { monitoring, feedback and } \\
\text { control—measure to manage }\end{array}$ & $\begin{array}{l}\text { Monitoring Structural and } \\
\text { Operational issuesunder } \\
\text { pressure from social and } \\
\text { environmental change }\end{array}$ & $\begin{array}{l}\text { Sustainability and Consumption } \\
\text { - To evaluate social/institutional/governance structures, } \\
\text { communication channels and information flow paths; } \\
\text { To include papers that address translational processes, } \\
\text { considering the societal context; } \\
\text { - To identify what kind of evaluation is in place, if any, } \\
\text { for obtaining information about the effectiveness and } \\
\text { success of schemes/programmes. }\end{array}$ \\
\hline $\begin{array}{l}\text { Utility of the } \\
\text { ideas/policies/schemes/ } \\
\text { mechanisms/theories }\end{array}$ & $\begin{array}{l}\text { Effectiveness and } \\
\text { efficiency—transformational } \\
\text { potential }\end{array}$ & $\begin{array}{l}\text { Sustainability and Consumption } \\
\text { - Search for information about the capacity (potential) of } \\
\text { schemes/policy to be used as a reference for regional, } \\
\text { national and EU-level regulation of socio-cultural } \\
\text { interactions with sustainable policy initiatives (all } \\
\text { levels); } \\
\text { Highlight where the } \\
\text { schemes / approaches/theories / policies have a } \\
\text { potential for success; } \\
\text { What are the useful outcomes of the measures in terms } \\
\text { of public compliance and satisfaction and in meeting } \\
\text { society's needs?; } \\
\text { Record any evidence of a rise in societal awareness, } \\
\text { public engagement or public good associated with } \\
\text { policy and support of issue(s) related to sustainability } \\
\text { and consumption; } \\
\text { Note the development of new research collaborations, } \\
\text { the reinforcement of existing research collaborations, } \\
\text { the development of new research areas and curricula, } \\
\text { the establishment of new research centres, stronger } \\
\text { collaboration across institutions and governments, etc. }\end{array}$ \\
\hline $\begin{array}{l}\text { Articles/Papers that reference } \\
\text { societal values }\end{array}$ & $\begin{array}{c}\text { Decision Theory, } \\
\text { Values and Social paradigms }\end{array}$ & $\begin{array}{l}\text { To explore the linked hierarchy of values and decision } \\
\text { making-contrasting and shifting realities of society. }\end{array}$ \\
\hline $\begin{array}{l}\text { Articles/Papers that explore } \\
\text { governance and institutions. }\end{array}$ & $\begin{array}{l}\text { Power, regulation, standards } \\
\text { and social context }\end{array}$ & $\begin{array}{l}\text { To expand the concepts of actors and influence in } \\
\text { institutional and political governance and social change. }\end{array}$ \\
\hline $\begin{array}{l}\text { Papers that address the nexus of } \\
\text { sustainability, consumption, } \\
\text { environment and } \\
\text { governance/control and the } \\
\text { socio-political context. }\end{array}$ & $\begin{array}{l}\text { Interaction, the Multidiscipline } \\
\text { or Cross-discipline focus or } \\
\text { Nexus }\end{array}$ & $\begin{array}{l}\text { To examine the dynamics and influence of linkages, choice } \\
\text { sets, nuances, etc., imbedded within the socio-political } \\
\text { context of consumption and sustainability. }\end{array}$ \\
\hline
\end{tabular}


Table 3. Cont.

\begin{tabular}{|c|c|c|}
\hline Eligibility Criteria & Categorisation & Comment/Analysis \\
\hline \multicolumn{3}{|c|}{ Methodological Approach } \\
\hline Theoretical reviews & $\begin{array}{l}\text { Methodology-Measurement } \\
\text { approach or key variable }\end{array}$ & $\begin{array}{l}\text { To ensure studies that address key theoretical } \\
\text { considerations and concept development are included. }\end{array}$ \\
\hline Qualitative studies & Methodology-Research design & $\begin{array}{l}\text { To ensure studies that address qualitative dimensions are } \\
\text { included. }\end{array}$ \\
\hline Quantitative studies & $\begin{array}{l}\text { Methodology- } \\
\text { Measurement/key } \\
\text { variable }\end{array}$ & $\begin{array}{l}\text { To exclude or limit studies which have little } \\
\text { theoretical/systems analysis, i.e., studies that are largely } \\
\text { quantitative in nature. }\end{array}$ \\
\hline \multicolumn{3}{|c|}{ Approaches to Data and Theory Analysis } \\
\hline $\begin{array}{l}\text { Evidence of data interrogation } \\
\text { and theoretical contribution to } \\
\text { sustainability, consumption and } \\
\text { governance. }\end{array}$ & New data and theory & $\begin{array}{l}\text { To identify papers with seminal interpretations or novel } \\
\text { interpretations of data. To identify papers that provide data } \\
\text { or theoretical contributions on the interplay between } \\
\text { consumption, sustainability, society and governance. }\end{array}$ \\
\hline $\begin{array}{l}\text { Evidence of insights and } \\
\text { analysis of sustainability and } \\
\text { consumption as dynamic } \\
\text { systems in the context of a } \\
\text { changing environmental, social } \\
\text { and political landscape. }\end{array}$ & $\begin{array}{l}\text { Models and Uncertainty } \\
\text { Approaches that advance } \\
\text { understanding of the change } \\
\text { paradigm }\end{array}$ & $\begin{array}{l}\text { To include papers that address the uncertainty principal. } \\
\text { Articles that make seminal contributions to the change } \\
\text { agenda-environmental change, social change and political } \\
\text { change. }\end{array}$ \\
\hline $\begin{array}{l}\text { Evidence of the role of } \\
\text { regulation and the UN SDGs in } \\
\text { shaping the decision-making } \\
\text { environment. }\end{array}$ & $\begin{array}{l}\text { Global and Regional Regulation } \\
\text { and policy conventions }\end{array}$ & $\begin{array}{l}\text { To include papers that address global and regional } \\
\text { regulation in the context of the 'Grand Challenges' of social } \\
\text { and environmental change. }\end{array}$ \\
\hline $\begin{array}{l}\text { Evidence of agile and smart } \\
\text { over-arching approaches to } \\
\text { sustainability and consumption } \\
\text { optimisation. }\end{array}$ & $\begin{array}{l}\text { Management, policy and } \\
\text { decision making }\end{array}$ & $\begin{array}{l}\text { To identify articles that are cross-cutting in outlook, have } \\
\text { general applicability, and provide evidence of adaptability } \\
\text { linked to the principles of the UN SDGs and key political } \\
\text { and social actors and drivers in society. }\end{array}$ \\
\hline
\end{tabular}

The extraction of data from the studies and articles was undertaken using an independent double semi-blind review approach (i.e., both authors independently and separately) to enhance concept mining, insight development and selection reliability. The authors were blind to each other's assessment outcomes during the review of selected core papers. Some authors have argued for a fully blind evaluation as to the journal from which the article came, the authors of the paper, their institutions, and the magnitude and direction of the results obtained. However, the Cochrane Report, used as the method guide in this study, also notes that this approach may not be warranted given the resources required and the uncertain benefit in terms of protecting against bias [46]. Comparisons were made within and across studies within the core papers based on an evaluation of their content including research approach, context, data, theoretical contributions and quality indicators. Thus, the characterisation profile of the final core SLR papers and the systematic data extraction process provided a sequential, structured and robust assessment of the contribution of each paper in addressing the research questions.

\subsection{Thematic Analysis-Interpretation and Synthesis}

The outputs of the SLR were analysed and categorised using thematic analysis set in the conceptual framework developed for eligibility and data extraction (Section 2.2 and Table 3) and interrogated using the established approach set out in Table 4 [37]. This approach sought to explore the concepts, theories, processes, actions and interactions reported in the core selected literature and informed by the conceptual framework of the methodological review. The endpoint of this analysis is the development of the 'building blocks' of a new theoretical model or construct that can provide a road map for the advancement of sustainable consumption policy. In exploring the data, the rate of occurrence of a theme or concept was documented. However, the focus of the thematic analysis was to 
look for patterns of occurrence of theories and concepts within the papers' and to utilise the conceptual framework to aid analysis.

Table 4. Thematic analysis phases.

\begin{tabular}{|c|c|c|}
\hline 1 & Familiarisation with data: & Transcribing data (if necessary), reading and re-reading the data, noting initial ideas. \\
\hline 2 & Generating initial codes: & $\begin{array}{l}\text { Coding interesting features of the data in a systematic fashion across the entire data set, } \\
\text { collating data relevant to each code. }\end{array}$ \\
\hline 3 & Searching for themes: & Collating codes into potential themes, gathering all data relevant to each potential theme. \\
\hline 4 & Reviewing themes: & $\begin{array}{l}\text { Checking if the themes work in relation to the coded extracts (Level 1) and the entire data } \\
\text { set (Level 2), generating a thematic 'map' of the analysis. }\end{array}$ \\
\hline 5 & $\begin{array}{l}\text { Defining and naming } \\
\text { themes: }\end{array}$ & $\begin{array}{l}\text { Ongoing analysis to refine the specifics of each theme, and the overall story the analysis } \\
\text { tells, generating clear definitions and names for each theme. }\end{array}$ \\
\hline 6 & Producing the report: & $\begin{array}{l}\text { The final opportunity for analysis. Selection of vivid, compelling extract examples, final } \\
\text { analysis of selected extracts, relating the analysis back to the research question and } \\
\text { literature, and producing a scholarly report of the analysis. }\end{array}$ \\
\hline
\end{tabular}

Source: adapted with permission from ref. [37], Copyright Year: 2006, Copyright Owner's Name: Taylor \& Francis.

The reporting of article content employed this strategic conceptual outlook and sought to extract meaning from patterns in the data developed and refined through an iterative and sequential process of identifying themes before, during, and after analysis (Table 4). The validity of this approach is dependent on a careful analysis of the data with reference to the underlying assumptions (theoretical underpinnings) of the framework adopted.

\subsubsection{Deductive Thematic Considerations}

Themes or patterns within the data were identified from a deductive or "top-down" perspective, in contrast to the inductive approach in which themes are shaped by the data in an unbounded manner $[47,48]$. This deductive or "theoretical" thematic analysis approach is driven by the defined theoretical or analytical interest in the area of consumption behaviour, sustainability and values, as defined earlier. This form of thematic analysis tends to provide a more detailed analysis of key aspects within the data (the core literature review papers). This involved coding the data with reference to the specific research questions (which map onto the theoretical underpinnings) and their associated objectives.

\subsubsection{Latent Approach to Theme Identification}

Another aspect of the approach concerned the "level" at which themes were identified: whether at a semantic or explicit level, or at a latent or interpretative level [47]. The semantic approach identifies themes within the explicit or surface meanings of the data. However, this work followed the latent approach, which goes beyond the semantic content of the data and starts to identify or examine the underlying ideas, assumptions, conceptualisations and ideologies that are theorised as shaping or informing the semantic content of the data. Thus, using latent thematic analysis, the development of the themes themselves involved interpretative work, and the analysis produced is not just description, but is already theorised or set in a theoretical context. Analysis within this latter tradition tends to come from a constructionist paradigm [49]. Thus, broader assumptions, structures and/or meanings are theorised as underpinning what is actually articulated in the data.

\subsubsection{Constructionist Thematic Analysis}

Thematic analysis can be conducted from either a realist/essentialist perspective or a constructionist paradigm. In the essentialist/realist approach, the data are interrogated and theorised in a largely unidirectional manner, linking meaning and experience. In contrast, the constructionist perspective interprets the data in the context of their social setting and seeks to theorise while recognising the socio-cultural contexts and structural conditions that define the data. This study adopted the constructionist model, which is consistent with the theoretical assumptions of the work. 


\subsubsection{Outputs of Thematic Analysis}

Thematic analysis has been presented as a method for identifying, analysing and reporting patterns (themes) within data. It organises and describes the data set in rich detail. Additionally, it typically develops further than this and provides the opportunity to interpret aspects of the research topic [47]. To this end, the literature review data were evaluated and analysed using the six phases of thematic analysis (Table 4) and with close reference to the original research questions and the structure set out in Table 3.

\section{Results}

In total, 89 databases were selected for consideration, including Scopus, JSTOR, Web of Science and the Social Sciences Citation Index. This approach generated a Master List of 349 papers and studies (Table 5). These papers were then screened using criteria not readily identifiable through the facilities of the 'Search Term' and 'Inclusion/Exclusion' processes offered in the database interrogation systems. Outcomes of this task emphasised the need to limit the study in terms of its time frame of reference and with regard to definitions on what constitutes the most appropriate societal-environmental focus of sustainability. In order to advance the assessment of the SLR literature and GL list and to ensure quality and consistency, the included studies and papers were then evaluated using eligibility criteria (Table 3).

Table 5. List of papers selected through the SLR process.

\begin{tabular}{ccc}
\hline Search All/Summon at TU Dublin-The Technological University Dublin Library Catalogue \\
\hline Search Terms & Boolean Operator & $\begin{array}{c}\text { Number of Articles } \\
\text { Identified, 17th January 2018 }\end{array}$ \\
\hline Sustainable & OR & \\
\hline Sustainability & AND & $1,175,290$ \\
\hline Environment & OR & 853,504 \\
\hline Environmentally & AND & 88,052 \\
\hline $\begin{array}{c}\text { Consumer Behaviour/ } \\
\text { Consumer Behaviour }\end{array}$ & AND & 23,095 \\
\hline Governance & AND & 21,492 \\
\hline Policy & AND & 20,036 \\
\hline Value & OR & 2370 \\
\hline Values & AND & 349 \\
\hline Intrinsic & AND & \\
\hline Extrinsic & & \\
\hline
\end{tabular}

The GL was included based on a 'hand-search' approach using a referral basis from the reference sections of the final core papers identified in the formal SLR approach. This process has high specificity and is only adopted where the contribution of the referred paper or study was deemed as fundamental. The GL also included relevant papers/reports and publications from within the databases of the Irish EPA and Irish Government/EU sources. This resulted in a GL master list of 87 papers, studies, publications and reports. The GL list was subjected to the same study selection, screening and eligibility assessment as the SLR literature. The SLR literature and the GL list were kept as separate data categories for clarity and tracking purposes.

The flowchart scheme of the Preferred Reporting Items for Systematic Reviews and Meta-Analyses (PRISMA) was tailored to the needs of this study and used to map the article extraction process (Figure 1) [43]. As such, the PRISMA checklist has been designed to ensure the complete and transparent reporting of the methods used in systematic reviews. 


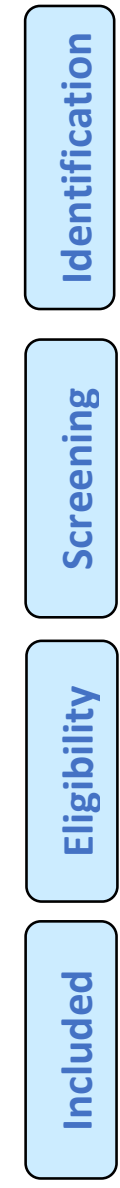

Records identified through database searching

$(\mathrm{n}=349)$

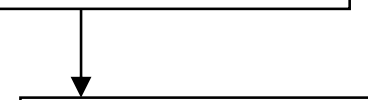

Records after duplicates removed

$(\mathrm{n}=408)$

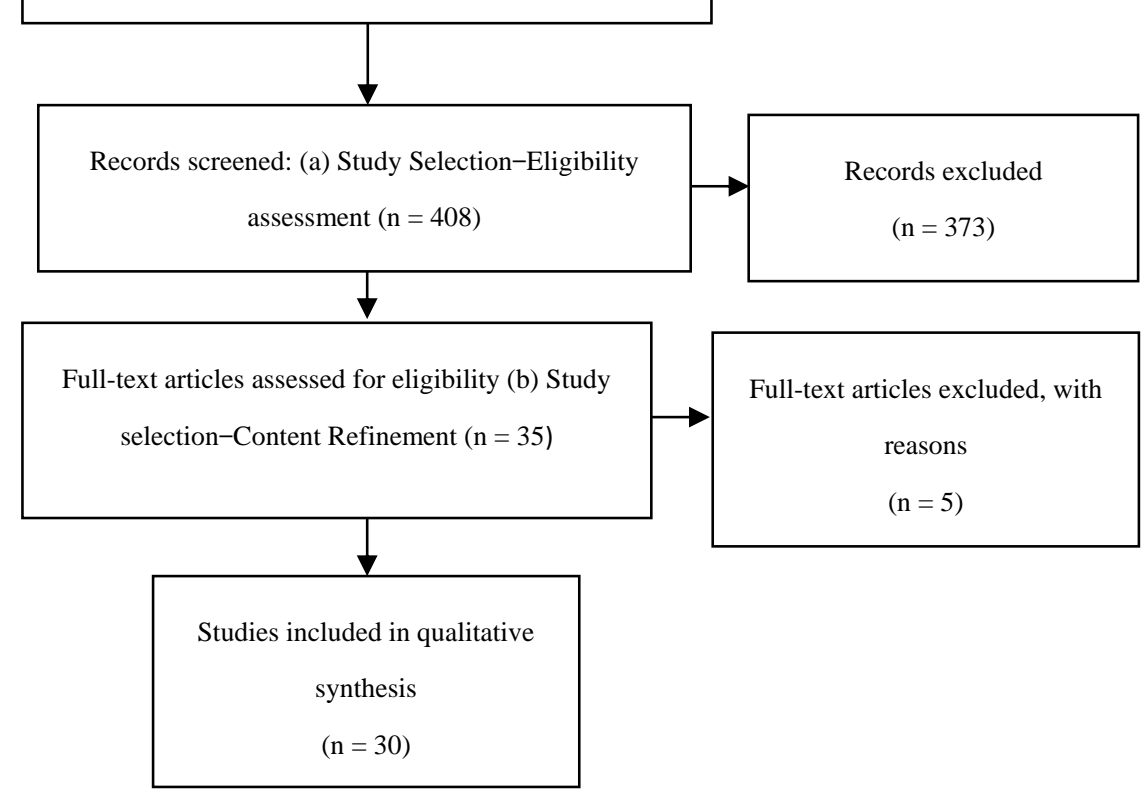

Figure 1. The PRISMA model of the SLR approach.

The scholarly literature was found to be widely distributed across different disciplinary journals of variable quality. The search of academic literature revealed a core list of 30 articles selected from 29 separate journals, with only one open access journal providing two articles. The journals/papers included the disciplines of consumer studies, geography, business, political science, economics, environmental management, environmental psychology, sociology, ecological economics, sustainability science, marketing, energy policy, education, communication, and ethics as well as cross disciplinary journals such as Emergence: Complexity and Organization (E:CO). This wide eclectic grouping was influenced by the research questions which, by their very nature, attempted to draw on publications addressing wider societal issues with regard to consumption, sustainability and values. Although data were extracted from the literature over the period of 2002-2018, the majority of the selected papers were published in the period since 2010. In total, there were three systematic literature review papers and one scoping literature review amongst those selected. An analysis of content of all 30 publications indicated a wide breadth of themes, the top ten of which included (in order of most frequent to less frequent); social concepts, behaviour, sustainability, values, policy, change, economics, consumption, knowledge and information. The concepts of society and responsibility, although the focus of some of the papers, featured less frequently than the more common arguments for consumer or citizen responsibility. This aspect was revealing in itself, but needs to be explored and set in a more nuanced and contextualised analytical framework.

Incorporating the utilitarian, the social/psychological, and the systems of provision/institutional approaches as a framework [3], as well as emerging themes from the literature, a schema of three dimensions was identified, refined and used to analyse the 
data emerging from the selected literature. This was also informed by recognition of the agency inherent in approaches to sustainability [40], including individualistic or consumer responsibility, individual, household or community consumption situated within wider social frameworks, and more 'systemic' conceptions of consumption as socio-technical systems $[5,42]$. Utilising these classifications $[3,40,41]$, the basic schema was developed. Thus, the data were explored using: (i) the utilitarian individualistic or consumer focus/responsibility perspective; (ii) the social/marketing perspective representing individual, household or community consumption situated within wider economic and technological frameworks of society and often with a more policy-oriented focus; and (iii) the systems of provision/institutional perspective based on a more 'systemic' view of consumption as a socio-technical system, originating from within a sociological outlook and with the possibilities of transformation to a more 'societally' responsible model with the involvement of wider institutional actors [5,41] (Figure 2).

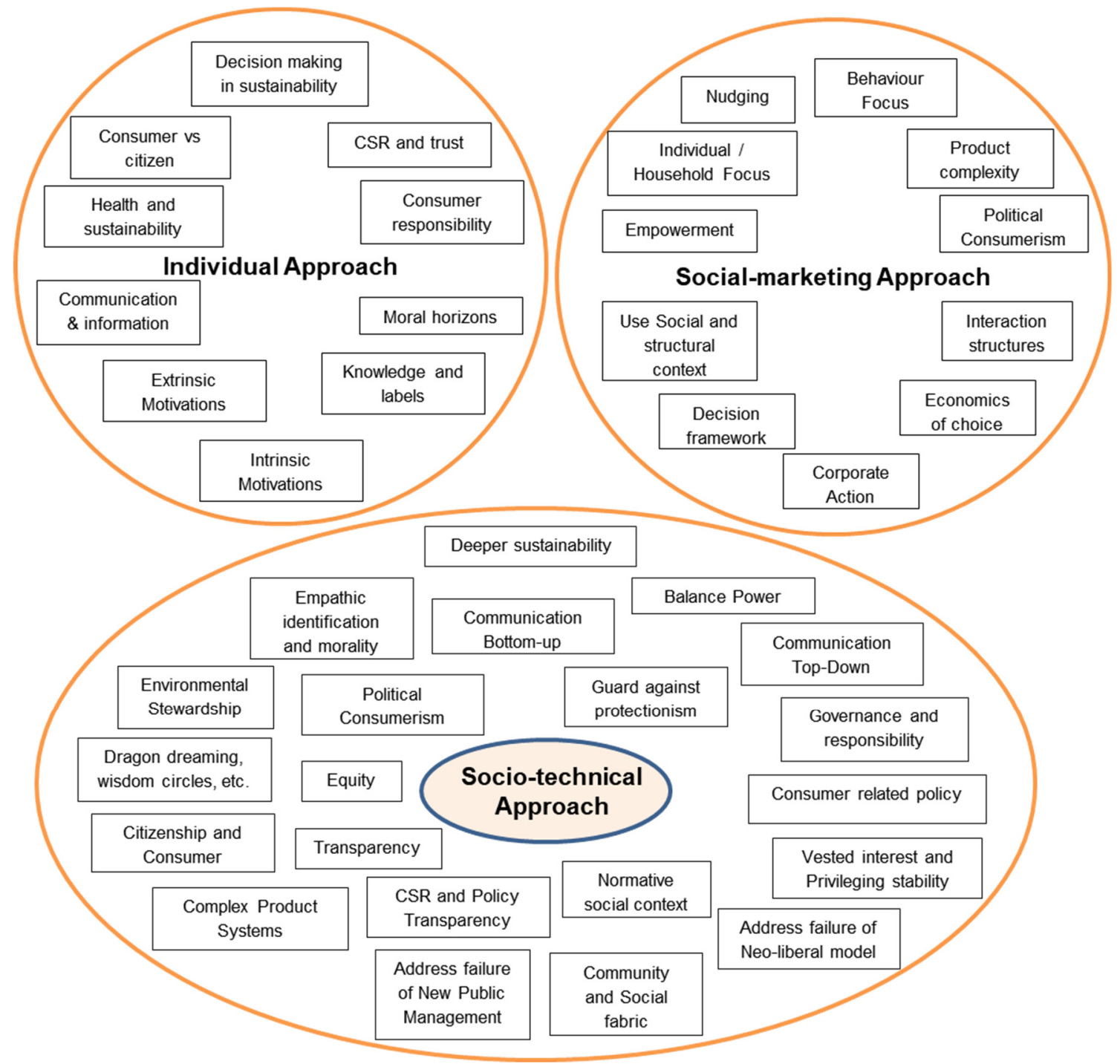

Figure 2. Thematic map, showing the theoretical framework and main themes.

\section{Discussion}

This paper sought to address the paradigm context of governance and policy approaches which recognise the importance of preserving the balance of nature and which acknowledge the inevitability of limits to growth. The outputs suggest that this is only pos- 
sible where a clear understanding exists regarding the sustainability challenge, behavioural systems within society, and their consumption dynamics and values. This research tackled this problem against a society dominated by a neo-liberal philosophy that typically places greater emphasis on extrinsic values, and by behavioural dynamics that often expound positive attitudes toward sustainability, but which exhibit mostly unsustainable consumption patterns [23].

\subsection{The Utilitarian Approach-The Individual as Responsible Consumer}

Although the search terms and inclusion/exclusion criteria employed by the study sought to identify the interplay of concepts that include both individual and society, the largest tranche of papers categorised by the process focused on the individual and their responsibilities in the consumption cycle. Some of the papers focused on the factors influencing an individual's decision-making processes, whether it be lack of education to inform more cognizant consumption, or recognition of the complex of pressures driving individuals (and institutions) in their attempts to make more sustainably motivated plans. Managers in institutions are often driven by a narrow set of constraints which may conflict wider sustainability concerns. A number of papers, through both a policy and consumption study lens, addressed the need to motivate individuals through reminding them of their responsibilities to future generations and sought to move their self-interest to encompass the recognition of 'public goods'. Other papers examined how scientists and other stakeholders need to deepen understanding of the nature of individual motivation and trust in order to influence individual behaviour. Those in the marketing and consumer disciplines seek to address this through utilising green branding, eco-labelling, second-hand purchasing, and green logistics, as well as calling for corporate social responsibility (CSR) to define business operations. This takes shape through the call for more sustainable consumption in retailing, embedding the triple bottom line in logistics, promotion of sustainable branding, and the encouragement and support for the business case of CSR. Those in the discipline of psychology impart interesting insights in terms of the processes of perception and communication. Some of the stewardship literature, although implying by its very description notions of broader governance, looks at decentralising responsibility which ultimately focuses on individual behaviour.

\subsection{The Social/Marketing Perspective}

Despite the focus from a policy perspective on the individual's responsibility, neoclassical economic models have failed to significantly influence sustainable consumption behaviour, nor has the availability of better-quality information changed behaviour [50]. The outcomes of this study support the critique that has come from two social/psychological sources: (i) behavioural economics, and (ii) consumption studies [3]. Behavioural economics and the influence of behavioural science recognises that individuals do not act rationally in decision-making; instead, they revert to familiar heuristics to process information more easily in decision making. Behavioural economics also recognises that decision making is influenced or constrained by the role of social norms and routines, including notions of community and fairness in economic outcomes [51]. Thus, individuals limit their information search, because information overload can lead to subsequent difficulties in decision making, although they recognise the importance of their decisions or actions for wider society [17]. These approaches are addressed by some of the papers in framing consumer theory, although they also note that the impact on consumers often remains highly contested. Indeed, the literature recognises that:

- Political support to enhance citizen-oriented choices is required;

- There is a need for social policies to redistribute resource consumption in a context of a no-growth scenario;

- Climate change necessitates evolution-technologically as a response to new or shifting ecological states, culturally to provide the context and leverage, and in regulatory terms to provide the vehicles to implement change; 
- Communication approaches that advocate individual voluntary action often ignore social and structural impediments to behaviour change;

- There is a need to develop a conceptual framework to analyse power and (dis)empowerment in transformative social change;

- There is a need to advance a conceptual model linking consumption with the status of population-environment literature;

- Institutional change theory identifies the taxonomy of power and how institutions can determine individual choice and interaction structures;

- Cases of collective action have been identified as exemplars or standards of corporate action in relation to environmental issues and used to leverage change;

- Communities and their interactions are critically important as a context for behavioural change.

\subsection{Socio-Technical Approach-Systems of Provision}

Sustainable consumption is a collective action problem and there are inherent difficulties facing groups of people trying to work together for the common good [52]. One of the most compelling characteristics of environmental problems is the social, cultural, political and economic structures within which they operate. Individuals are often faced with making daily decisions in a setting and context they did not create, in terms of who has political power, who has control over resources, and, in a broader sense, what infrastructural and technological options are available and why. What is well noted is the imperative of social and cultural systems to change, to adapt, and evolve to meet the sustainability challenges at all levels [53]. Thus, interrogating the SLR literature (including GL content) from a socio-technical consideration views the data from an institutional and governance context and asks the question of who is really responsible for the development and practice of sustainable behaviour in our society and how this can be progressed. The evidence of this study suggests that this area has received less attention than that of the individual consumer or individual social-marketing perspective; however, it is this area that holds the greatest promise for real change in consumption behaviour. At its simplest, level governance and institutional activity can more sweepingly normalise choice arrays and define consumption impacts than providing the consumer with options of varying sustainability, outsourcing responsibility and waiting for them to choose. It is an imperative that governments engage with a deeper sustainability model and that this is reflected in societies, through investment in infrastructure, technology development and the will and means to enable implementation. Thus, the data suggest that a sustainable future cannot be achieved by relying solely on initiating a 'bottom-up' approach which seeks changes in individual consumer behaviour; moreover, a macro-institutional approach to sustainability in governance, policy and research is vital [23]. A number of papers have addressed these issues, advocating the need for policy and regulatory frameworks to be inter-connected in order to handle conflicting objectives of economics, environment and social justice. One paper called for a shift in thinking to recognise that markets can, in ways, subvert democracy and challenged the presumption that competitive markets are necessary for organising economic activity. Exploration of the literature data suggests that:

- People do not adopt sustainable consumption lifestyles for societal reasons; rather, cultural norms, institutional inertia and powerful actors, as well as individual reasons all conspire to fashion the output observed and experienced;

- Communication is not enough for consumer awareness and behavioural change-its understanding is often misplaced or misunderstood or even re-directed where its seen as contrary to accepted patterns;

- A new conceptual framing is needed which defines a culture of sustainability embodying individual practices but more significantly changing social institutions, societal norms and governance systems-indeed, the need for developing a sustainable global society is advocated; 
- There is a need to build concepts around an ethical society—linking an individual's worldview with planned societal or citizenship activities to ensure society continuously improves its ethical behaviour;

- Sustainability is a 'Grand Challenge' and requires 'Grand Governance', where the meaning and role of the citizen is elevated beyond paternalistic platitudes. There is a need for a new meaning of citizenship and for the state to reflect a deeper sustainability model.

\subsection{The Governance and Sustainability Policy Development (GSPD) Framework}

This paper suggests the synthesis of 27 principles as a Governance and Sustainability Policy Development (GSPD) Framework (Figure 3), and that these principles should be acknowledged in policy development designed to address sustainability in consumption and to inform a deeper embeddedness of sustainability in citizenship and governance. These evidence-based principles were derived from the above analysis and interrogation of the data and are set out under three themes: (i) the individual as a responsible consumer; (ii) the individual within the social, marketing and institutional context; and (iii) institutional and governance approaches. By building on the three thematic approaches to the analysis and exploration of a core body of systematically selected literature, it has been possible to develop a schema of 27 principles set around the four pillars of (i) Society, (ii) Economic systems, (iii) Consumers/citizens, and (iv) Governments and institutions. This schema seeks to guide future thinking in this complex field of sustainable consumption from both a policy and research perspective [54]. Furthermore, the use of the three theoretical considerations has thrown up some interesting insights which demonstrate the limitations of many current approaches to managing sustainable consumption in society. However, through an interrogation and synthesis of concepts and contexts within the literature data and ultimately by viewing these efforts firmly within a socio-technical (systems of provision/institutional) lens, it has been possible to fashion a new Governance and Sustainable Policy Development Framework (GSPD) model (Figure 3).

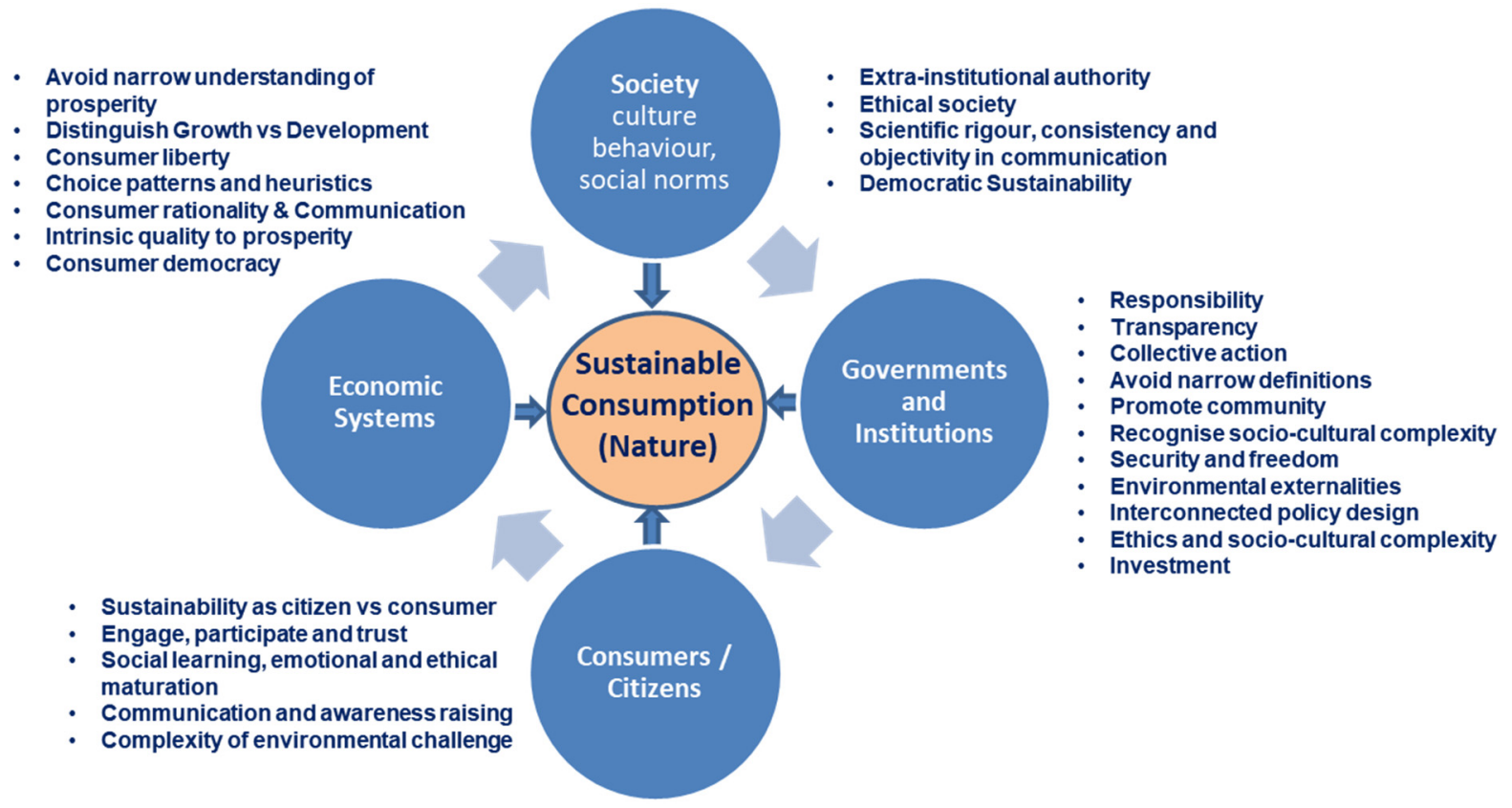

Figure 3. Governance and Sustainable Policy Development Framework (the 'Road Map') comprising the pillars of the framework and the 27 principles of change.

This structured approach or framework with its four pillars maps the context within which its embedded principles can be enacted. It also presents a number of parallels with seminal contributions within the broader literature $[41,55,56]$. It is a unique evidence-based 
contribution to the sustainable consumption literature and emphasises the importance of moving beyond the concept of the responsible consumer to encompass the interaction between society's complex infrastructures and human behaviour. In this sense, society itself, and its substructures, are recognised as complex socio-technical systems.

\section{Conclusions}

This study sought to explore the nature of governance (institutional and political) and the processes shaping the socio-economic paradigm relating to consumption, the sustainability agenda, and the limits to growth. This was undertaken through a full search of peer-reviewed academic publications and relevant grey literature in order to reveal the state of existing knowledge and understanding and to synthesise novel contributions linking current thinking, ideas and concepts in a new model-the building blocks of a roadmap to a new environmental paradigm. This is a 'Grand Challenge' because it strikes at the very heart of the sustainability argument, it recognises the heightened tensions in global and local economic and socio-cultural rhetoric, and proposes a new framework in a way that has not been done before, which uses an evidence-based approach to cut across much of the established ideology driven by the neo-liberal agenda.

This paper sought to gain further understanding of the values and motivations that influence consumption behaviour and sustainability. Consumer values, both intrinsic and extrinsic, are discussed against the backdrop of a society dominated by a neo-liberal philosophy which places greater emphasis on extrinsic values, and by behavioural approaches that expound positive attitudes toward sustainability, although exhibit mostly unsustainable consumption patterns [23]. This paper adopted an existing framework for the evaluation of behavioural approaches [3] modified to reflect the categorisation of agency in mapping data [40] as an aid to the analysis of the literature on the governance of sustainable consumption. This was manifest in the three key research questions:

- What societal dynamics drive consumption behaviour and how is environmental sustainability integrated into the decision-making process at a governance, institutional, community and individual level?

- What intrinsic and extrinsic dimensions of society control sustainable behaviour and decision making at the individual, institutional, community and governance level?;

- What is the most effective approach (road map) to the design of strategies, policies, initiatives, programmes and plans that can advance individual and societal behaviour and institutional and governance systems towards a more environmentally sustainable state?

Addressing these questions has provided insight on the selection of policy tools to change behaviours, but it also helps recognise how such tools are related to different modes of governance and act as frameworks to shape and form policy paradigms. However, much of the evidence suggests a failure to recognise the importance of social structures in affecting behaviour, and this has created a path dependency in which solutions to consumption are only accepted within the dominant governance and behavioural paradigm-this needs to be challenged [3].

Findings from the literature include difficulties in agreeing a common definition on what sustainability actually means and how to achieve it, as well as a lack of consideration of the wider social dimension and poor recognition of the complexity of sustainable behaviour as an iterative process. These challenges are pressing as the political system struggles to match the twin demands of economic prosperity while protecting and enhancing environmental quality for the well-being of society and the health of citizens. The imperative that emerges from this study is a recognition of the need to build innovative relationship networks in society, in which the value of sustainability is created. This approach is optimal when this process is collaborative rather than individual; thus, norms are re-defined, and society is guided towards a more integrated model with the potential to bring about system-shaping innovations. This innovative process can be seen as the set of 
connected actions that shift a system such as a community, a sector or an economy towards a more sustainable path.

This research study sought to inform a conceptual framework on how sustainable consumption can be advanced at a political and policy level through building on a systematic evidence-based examination of the literature across many disciplines and outlets. It presents a guidance framework or policy 'road map' for change that adds to the momentum that will drive this process forward. The presented governance and sustainability policy framework addresses the four key pillars of society, including individual consumers, society and culture, economic systems, and governance and institutions. The 27 guiding principles of change within the Governance and Sustainable Policy Development Framework represent core values that should be used to define how sustainability should be integrated in policy development. The changes required for sustainability in its widest sense may become politically charged, because 'expand or perish' is an inexorable force in a capitalist economic system [15]. The contradiction of seeking to influence the consumption patterns of the citizen-consumer, whilst capitalist actors seek continued increases in sales and profits, with no interest in societal benefits, is clear. Linking the macro approach of new institutionalism in recognising the impact of the institutional or societal logic of capitalist economics, on the culture and practice in consumption, is crucial. Implementation of sustainability policies must be a change not only in individual practices, but in the mind-set of wider society and governance systems. Calls have been made for the development of new forms of environmental authority, beyond nation states, in order to bring about effective forms of global governance for sustainable consumption in a new world order [6]. Other contributors recognise the call for action, citing the UN-SDGs as a framework, and the speech of their proposer, the former UN Secretary General H. E. Ban Ki-Moon, that "There is no Plan B for action, as there is no Planet B." [8]. They cite the moral imperative in that we all must act to guide business leaders, employees, and stakeholders with systematic, unbiased, and empirically robust evidence on mechanisms with which to tackle the persistent, but tractable, global problems confounding us. This study informs a conceptual road map and adds to the momentum that will drive this process forward.

Further research needs to be undertaken that directly addresses the consequences of seeking to manage fundamentally natural systems from a standpoint which is highly market-led and which seeks to disown responsibility and promote a subsidiarity-based model in sustainable management with the consumer as the intended target. Much of this approach challenges the established conventions inherent within the neo-liberal agenda of contemporary governance, which emphasises the imperative of why this line of research needs to be advanced. A limitation presented in this paper is the level of objectivity inherent in the semi-blind review process and the generation of agreement in the extracted data. The commitment of additional resources in terms of time and the engagement of a wider body of investigators would do much to minimise the issues of uncertainty attached to the data mining process. Expanding this methodological process and driving the research agenda against the rhetoric of outsourcing responsibility for sustainability in consumption must surely be the focus of renewed effort.

Author Contributions: The authors contributed equally to this work. All authors have read and agreed to the published version of the manuscript.

Funding: This research was funded by Irish Environmental Protection Agency, Grant number 2016-SE-DS-15.

Institutional Review Board Statement: Not applicable.

Informed Consent Statement: Not applicable.

Data Availability Statement: The raw/lab data is not publically archived. The papers of the SLR are available through the authors.

Conflicts of Interest: The authors declare no conflict of interest. 


\section{References}

1. Hermwille, L. Climate Change as a Transformation Challenge. A New Climate Policy Paradigm? GAIA Ecol. Perspect. Sci. Soc. 2016, 25, 19-22. [CrossRef]

2. Hall, C.M. Policy learning and policy failure in sustainable tourism governance: From first- and second-order to third-order change? J. Sustain. Tour. 2011, 19, 649-671. [CrossRef]

3. Hall, C.M. Framing behavioural approaches to understanding and governing sustainable tourism consumption: Beyond neoliberalism, "nudging" and "green growth"? J. Sustain. Tour. 2013, 21, 1091-1109. [CrossRef]

4. Shove, E. Putting practice into policy: Reconfiguring questions of consumption and climate change. Contemp. Soc. Sci. 2012, 9 , 415-429. [CrossRef]

5. Geels, F.W.; McMeekin, A.; Mylan, J.; Southerton, D. A critical appraisal of Sustainable Consumption and Production re-search: The reformist, revolutionary and reconfiguration positions. Glob. Environ. Chang. 2015, 34, 1-12. [CrossRef]

6. Spaargaren, G. Theories of practices: Agency, technology, and culture: Exploring the relevance of practice theories for the governance of sustainable consumption practices in the new world-order. Glob. Environ. Chang. 2011, 21, 813-822. [CrossRef]

7. Dietz, T.; Gardner, G.T.; Gilligan, J.; Stern, P.C.; Vandenbergh, M.P. Household actions can provide a behavioral wedge to rapidly reduce US carbon emissions. Proc. Natl. Acad. Sci. USA 2009, 106, 18452-18456. [CrossRef]

8. George, G.; Howard-Grenville, J.; Joshi, A.; Tihanyi, L. Understanding and tackling societal grand challenges through management research. Acad. Manag. J. 2016, 59, 1880. [CrossRef]

9. Barr, S.; Gilg, A.; Shaw, G. Citizens, consumers and sustainability: (Re)Framing environmental practice in an age of climate change. Glob. Environ. Chang. 2011, 21, 1224-1233. [CrossRef]

10. Davies, A.; Fahy, F.; Rau, H.; Devaney, L.; Doyle, R.; Heisserer, B.; Hynes, M.; Lavelle, M.J.; Pape, J. Consensus: Consumption, Environment and Sustainability; EPA Research Report No 138; Environmental Protection Agency: Dublin, Ireland, 2014.

11. Davies, A.R.; Fahy, F.; Rau, H. (Eds.) Challenging Consumption: Pathways to a More Sustainable Future; Routledge: Abington, UK, 2014.

12. Carragher, V.; McCormack, S. Identifying, Reviewing and Testing the Factors that Drive the Sustainable Behaviour and Transition of Communities, Groups and Individual; EPA Research Report No 238; Environmental Protection Agency: Dublin, Ireland, 2018.

13. DEFRA Department for Environment, Food and Rural Affairs. Changing Behaviour through Policy Making; The Stationery Office: London, UK, 2005.

14. DEFRA Department for Environment, Food and Rural Affairs. A Framework for Pro-Environmental Behaviours; The Stationery Office: London, UK, 2008.

15. Hoffmann, U. Some Reflections on Climate Change, Green Growth Illusions and Development Space, 2011, UNCTAD Discussion Paper No. 205; United Nations Conference on Trade and Development: Geneva, Switzerland, 2011.

16. Koch, M. Capitalism and Climate Change: Theoretical Analysis, Historical Development and Policy Responses; Palgrave Macmillan: Basingstoke, UK, 2012.

17. Seyfang, G. The New Economics of Sustainable Consumption: Seeds of Change; Palgrave Macmillan: Basingstoke, UK, 2009.

18. Bone, J.D. Irrational Capitalism: The Social Map, Neoliberalism and the Demodernization of the West. Crit. Sociol. 2010, 36, 717-740. [CrossRef]

19. Simon, H.A. Administrative Behavior, 2nd ed.; Free Press: New York, NY, USA, 1965.

20. Alemanno, A. Nudging Smokers The Behavioural Turn of Tobacco Risk Regulation. Eur. J. Risk Regul. 2012, 3, 32-42. [CrossRef]

21. Jones, R.; Pykett, J.; Whitehead, M. Governing temptation: Changing behaviour in an age of libertarian paternalism. Prog. Hum. Geogr. 2010, 35, 483-501. [CrossRef]

22. Shove, E. Beyond the ABC: Climate Change Policy and Theories of Social Change. Environ. Plan. A Econ. Space 2010, 42, 1273-1285. [CrossRef]

23. Prothero, A.; Dobscha, S.; Freund, J.; Kilbourne, W.E.; Luchs, M.G.; Ozanne, L.K.; Thøgersen, J. Sustainable Consumption: Opportunities for Consumer Research and Public Policy. J. Public Policy Mark. 2011, 30, 31-38. [CrossRef]

24. Higham, J.; Cohen, S.A.; Peeters, P.; Gössling, S. Psychological and behavioural approaches to understanding and governing sustainable mobility. J. Sustain. Tour. 2013, 21, 949-967. [CrossRef]

25. Moloney, S.; Horne, R.E.; Fien, J. Transitioning to low carbon communities—from behaviour change to systemic change: Lessons from Australia. Energy Policy 2010, 38, 7614-7623. [CrossRef]

26. McDonagh, P.; Prothero, A. Sustainability marketing research: Past, present and future. J. Mark. Manag. 2014, 30, 1186-1219. [CrossRef]

27. Dunlap, R.E. Paradigms, theories and environmental sociology. In Sociological Theory and the Environment: Classical Foundations, Contemporary Insight; Dunlap, R.E., Buttel, F.H., Dickens, P., Gijswijt, A., Eds.; Rowman and Littlefield: Lanham, MD, USA, 2002; pp. 329-350.

28. Dunlap, R.E. The NEP Scale: From marginality to worldwide use. J. Environ. Educ. 2008, 40, 3-18. [CrossRef]

29. Kilbourne, W.; McDonagh, P.; Prothero, A. Sustainable Consumption and the Quality of Life: A Macromarketing Challenge to the Dominant Social Paradigm. J. Macromark. 1997, 17, 4-24. [CrossRef]

30. European Commission. Europe 2020: A European Strategy for Smart, Sustainable and Inclusive Growth; European Commission: Brussels, Belgium, 2010. 
31. Haines, A.; Alleyne, G.; Kickbusch, I.; Dora, C. From the Earth Summit to Rio+20: Integration of health and sustainable de-velopment. Lancet 2012, 379, 2189-2197. [CrossRef]

32. Baumeister, R.F.; Leary, M.R. Writing narrative literature reviews. Rev. Gen. Psychol. 1997, 3, 311-320. [CrossRef]

33. Adams, R.; Jeanrenaud, S.; Bessant, J.; Denyer, D.; Overy, P. Sustainability-oriented Innovation: A Systematic Review. Int. J. Manag. Rev. 2016, 18, 180-205. [CrossRef]

34. Chandler, J.; Higgins, J.P.T.; Deeks, J.J.; Davenport, C.; Clarke, M.J. Chapter 1: Introduction. In Cochrane Handbook for Systematic Reviews of Interventions version 5.2.0; [updated June 2017]; Higgins, J.P.T., Churchill, R., Chandler, J., Cumpston, M.S., Eds.; The Cochrane Collaboration: London, UK, 2017. Available online: www.training.cochrane.org/handbook (accessed on 10 January 2018).

35. Denyer, D.; Tranfield, D. Producing a systematic review. In The Sage Handbook of Organizational Research Methods; Buchanan, D., Bryman, A., Eds.; Sage: London, UK, 2009.

36. Welch, V.; Petticrew, M.; Tugwell, P.; Moher, D.; O’Neill, J.; Waters, E.; White, H. The PRISMA-Equity Bellagio group PRISMAEquity 2012 Extension: Reporting Guidelines for Systematic Reviews with a Focus on Health Equity. PLoS Med. 2012 , 9, e1001333. [CrossRef] [PubMed]

37. Braun, V.; Clarke, V. Using thematic analysis in psychology. Qual. Res. Psychol. 2006, 3, 77-101. [CrossRef]

38. Dixon-Woods, M. Using framework-based synthesis for conducting reviews of qualitative studies. BMC Med. 2011, 9, 39. [CrossRef]

39. Thomas, J.; Newman, M.; Oliver, S. Rapid evidence assessments of research to inform social policy: Taking stock and moving forward. Evid. Policy J. Res. Debate Pract. 2013, 9, 5-27. [CrossRef]

40. Sedlacko, M.; Martinuzzi, A.; Røpke, I.; Videira, N.; Antunes, P. Participatory systems mapping for sustainable consumption: Discussion of a method promoting systemic insights. Ecol. Econ. 2014, 106, 33-43. [CrossRef]

41. Fuchs, C. Critical Social Theory and Sustainable Development: The Role of Class, Capitalism and Domination in a Dialectical Analysis of Un/Sustainability. Sustain. Dev. 2017, 25, 443-458. [CrossRef]

42. Shackley, S.; Green, K. A conceptual framework for exploring transitions to decarbonised energy systems in the United Kingdom. Energy 2007, 32, 221-236. [CrossRef]

43. Liberati, A.; Altman, D.G.; Tetzlaff, J.; Mulrow, C.; Gøtzsche, P.C.; Ioannidis, J.P.A.; Clarke, M.; Devereaux, P.J.; Kleijnen, J.; Moher, D. The PRISMA statement for reporting systematic reviews and meta-analyses of studies that evaluate health care interventions: Explanation and elaboration. PLoS Med. 2009, 6, e1000100. [CrossRef] [PubMed]

44. Pope, C.; Ziebland, S.; Mays, N. Analysing Qualitative Data. In Qualitative Research in Health Care; Wiley: Hoboken, NJ, USA, 2007; pp. 63-81.

45. Tong, A.; Flemming, K.; McInnes, E.; Oliver, S.; Craig, J. Enhancing transparency in reporting the synthesis of qualitative research: ENTREQ. BMC Med. Res. Methodol. 2012, 12, 181. [CrossRef]

46. Higgins, J.P.T.; Altman, D.G.; Sterne, J.A.C. Chapter 8: Assessing risk of bias in included studies. In Cochrane Handbook for Systematic Reviews of Interventions. Version 5.2.0; [updated June 2017]; Higgins, J.P.T., Churchill, R., Chandler, J., Cumpston, M.S., Eds.; The Cochrane Collaboration: London, UK, 2017. Available online: www.training.cochrane.org/handbook (accessed on 10 January 2018).

47. Boyatzis, R.E. Transforming Qualitative Information: Thematic Analysis and Code Development; Sage Publishing: Thousand Oaks, CA, USA, 1998.

48. Hayes, N. Theory-led thematic analysis: Social identification in small companies. In Doing Qualitative Analysis in Psychology; Hayes, N., Ed.; Taylor \& Francis Psychology Press: Erlbaum, UK, 1997.

49. Burr, V. An Introduction to Social Constructionism; Routledge: London, UK, 2006; ISBN 0-203-13302-1.

50. Whitmarsh, L. Behavioural responses to climate change: Asymmetry of intentions and impacts. J. Environ. Psychol. 2009, 29, 13-23. [CrossRef]

51. Folmer, H.; Johansson-Stenman, O. Does Environmental Economics Produce Aeroplanes Without Engines? On the Need for an Environmental Social Science. Environ. Resour. Econ. 2011, 48, 337-361. [CrossRef]

52. Soper, K. Re-thinking the Good Life: The citizenship dimension of consumer disaffection with consumerism. J. Consum. Cult. 2007, 7, 205-229. [CrossRef]

53. Tonn, B.; Stiefel, D. The Race for Evolutionary Success. Sustainability 2012, 4, 1787-1805. [CrossRef]

54. Byers, V.; Gilmer, A. Beyond Neoliberalism: Values and Sustainable Consumption Behaviour 2017-2018; Environmental Protection Agency: Wexford, Ireland, 2019; ISBN 978-1-84095-841-6.

55. Kollmuss, A.; Agyeman, J. Mind the Gap: Why do people act environmentally and what are the barriers to pro-environmental behaviour? Environ. Educ. Res. 2002, 8, 239-260. [CrossRef]

56. Phipps, M.; Ozanne, L.K.; Luchs, M.G.; Subrahmanyan, S.; Kapitan, S.; Catlin, J.R.; Gau, R.; Naylor, R.W.; Rose, R.L.; Simpson, B. Understanding the inherent complexity of sustainable consumption: A social cognitive framework. J. Bus. Res. 2013, 66, 1227-1234. [CrossRef] 